\title{
Economic-financial analysis of the use of biscuit bran as an energy alternative in diets for confined lambs
}

\section{Análise econômico-financeira do uso de farelo de biscoito como alternativa energética em dietas para cordeiros confinados}

\author{
Luiza de Nazaré Carneiro da Silva ${ }^{1 *}$; Aline Vieira Landim²; Hélio Henrique Araújo \\ Costa ${ }^{3}$; Wilder Hernando Ortiz Vega3; Clésio dos Santos Costa4; Ricardo Alves de \\ Araújo5; Renata Teixeira Alencar6; Luiz Carlos Oliveira de Sousa7
}

\section{Highlights}

The systems of rearing sheep need more capital with supply.

The rearing of sheep with biscuit bran provides positive total factor productivity.

Even in the most unfavorable situations, economic indicators are still attractive.

The biscuit bran does not compromise the economic viability of the systems.

\begin{abstract}
The objective of this study was to evaluate the economic and financial viability of replacing corn with biscuit bran (BB) in diets for Morada Nova lambs in feedlot. Twenty lambs confined with initial body weight of 17.00 $\pm 3.74 \mathrm{~kg}$ were used, arranged in four treatments, diet without biscuit bran (BB) and diets containing 15 , 30 or $45 \%$ of biscuit bran in place of corn in the diet. Data, expenses and revenues of the activity were obtained during the period of January 2020 in the municipality of Sobral, Ceará. The economic and financial evaluation was carried out descriptively, using Excel ${ }^{\circledR}$ spreadsheets. In the scenarios evaluated, feeding, animal acquisition and labor costs were the items that most contributed to production costs. The highest food costs were observed in the system that used $15 \%$ of BB, representing about $32.86 \%$ of the total costs. The simulation for sheep production provided revenue higher than the production costs in all diets tested, resulting in positive economic indicators. On the other hand, although the system that uses diet without

1 Student of Doctoral in Tropical Animal Science, Federal University of Tocantins, UFT, Araguaína, TO, Brazil. E-mail: luiza. zootecnia@gmail.com

2 Prof., State University of Vale of Acarajú, UVA, Sobral, CE, Brazil. E-mail: alinelandim@yahoo.com.br

3 Doctor in Animal Science, State, UVA, Sobral, CE, Brazil. E-mail: helio.costa@gmail.com; wilortvet@yahoo.es

${ }^{4}$ Student of Doctoral of in Animal Science, Federal University of Ceará, UFC, Fortaleza, CE, Brazil. E-mail: clesiosantzoo@ gmail.com

5 Professor, State University of Maranhão, UEMA, Itapecuru Mirim, MA, Brazil. E-mail: ricardo_zoo@hotmail.com

${ }^{6}$ Master in Animal Science, UVA, Sobral, CE, Brazil. E-mail: renata.teixeira.alencar@gmail.com

7 Student of Master's in Animal Science, Federal University of Viçosa, UFV, Viçosa, MG, Brazil. E-mail: luizcarlosoliveira111@ gmail.com

* Author for correspondence
\end{abstract}

Received: May 15, 2020 - Approved: Oct. 13, 2020 
biscuit bran provides positive revenue, net income was the lowest $\left(R \$ 12,117.15\right.$ year $\left.^{-1}\right)$. It was observed that all scenarios had a leveling point higher than $5,000 \mathrm{~kg}$ of meat year-1. The total productivity of the factors of all treatments evaluated was higher than 1, which indicates that the activity is stable, presenting high internal rates of return. Similarly, profitability rates are attractive, especially for diets containing BB, where the net present value is higher ( $R \$ 362,143.26)$. Sensitivity analyses showed that even in the most unfavorable situations, such as a $30 \%$ reduction in production and market price, indicators are economically viable. The use of $\mathrm{BB}$ does not compromise the economic viability of the diet compared to the diet without $\mathrm{BB}$, they present higher profitability, especially at the level of $15 \%$ in the diet.

Key words: Alternative food. Economic evaluation. Production costs. Productivity. Revenue.

\section{Resumo}

Objetivou-se avaliar a viabilidade econômico-financeira da substituição do milho por farelo de biscoito (FBISC) em dietas para cordeiros Morada Nova em confinamento. Foram utilizados 20 cordeiros confinados com peso corporal inicial de 17,00 $\pm 3,74 \mathrm{~kg}$, dispostos em quatro tratamentos, sendo dieta sem farelo de biscoito e dietas contendo 15, 30 ou $45 \%$ de farelo de biscoito em substituição ao milho na dieta. Os dados, as despesas e as receitas da atividade foram obtidas durante o período de janeiro de 2020 no município de Sobral, Ceará. A avaliação econômico-financeira foi realizada de forma descritiva, utilizandose as planilhas do Excel ${ }^{\circledR}$. Nos cenários avaliados, a alimentação, a aquisição dos animais e os custos com mão-de-obra foram os itens que mais contribuíram para os custos de produção. Os maiores custos com alimentação foram observados no tratamento que utilizou 15\% de FBISC, representando cerca de 32,86\% dos custos totais. A simulação para produção de ovinos proporcionou receita superior aos custos de produção em todas as dietas testadas, resultando em indicadores econômicos positivos. Por outro lado, apesar da criação que usa dieta sem farelo de biscoito proporcionar receita positiva, a renda líquida foi a menor ( $\mathrm{R} \$ 12.117,15 \mathrm{ano}^{-1}$ ). Observou-se que todos os cenários tiveram ponto de nivelamento superior a $5.000 \mathrm{~kg}$ de carne $a^{-1}$. A produtividade total dos fatores de todos os tratamentos avaliados foi maior que 1, o que indica que a atividade é estável, apresentando altas taxas internas de retorno. Da mesma forma, os índices de lucratividade são atrativos, principalmente para as dietas contendo FBISC, onde o valor presente líquido é maior ( $R \$ 362.143,26)$. As análises de sensibilidade mostraram que até mesmo nas situações mais desfavoráveis, tais como a redução de $30 \%$ na produção e no preço de mercado, os indicadores são economicamente viáveis. O uso do FBISC não compromete a viabilidade econômica da dieta comparada a dieta sem FBISC, apresentam maior rentabilidade, com destaque ao nível de 15\% na dieta.

Palavras-chave: Alimento alternativo. Avaliação econômica. Custos de produção. Produtividade. Receita.

\section{Introduction}

In sheep production, so that the finishing phase is productive there is the necessity of well-developed animals. Thus, in this phase is of the utmost importance well-nourished and developed physiologically sheep. It is worth mentioning that, within a rural property, termination represents a major source of spending, especially with food (Araújo et al., 2018; Bortoli, Monteiro, Gameiro, \& Bianchi, 2018). On this basis, the use of alternative food can make this phase more efficient from an economic point of view, because these foods can reduce the production cost. 
The studies that perform economic analysis of sheep with alternative foods are scarce and, in most cases, are incomplete not composing the total production cost. These studies are of utmost importance to evaluate better the activity and that it is possible to reduce costs, increase productivity, and establish goals with the aim of achieving high profitability with efficiency and sustainability of the business. In this context, the residues of the baking industry emerge as an alternative feed for ruminants in the Brazilian semiarid, may replace corn, is a noble food and used in human food, which increases production costs (Araújo et al., 2020a).

It is emphasized that the Brazilian agribusiness sector is responsible for a large part of gross domestic product (GDP), livestock has great importance in this increase given that the demand for animal protein increases rapidly in Brazil and worldwide. Therefore, investment in animal production is an alternative to make money profitable and generate profits for the producer (Arriba \& Andrés, 2014), considering that the money invested in the production correctly can generate a higher return than that applied in the savings account, depending on the conical scenario related to the interest rate (Araújo et al., 2020b). Thus, integrating the industry into agriculture can be attractive for both.

It is also noteworthy that sheep farming is an important livestock activity in Brazil and is under going into restructuring. Its production extends throughout the national territory, being a source of income and subsistence, however, there is an imbalance between supply and demand of the product. This imbalance generates an excess demand for sheep meat, which determines the need to purchase the product in the foreign market, while the expansion of marketing in niches stimulates demand for the product (Viana, Moraes, \& Dorneles, 2015).

In view of the above, this study aimed to evaluate the economic and financial viability of replacing corn with biscuit meal in diets for Morada Nova lambs in feedlot.

\section{Material and Methods}

The information of the technical parameters for financial analysis of this research were obtained in the Laboratory of Research in small ruminants of Universidade Estadual Vale do Acaraú - UVA, in the city of Sobral, Ceará, Brazil, in the period from December 2016 to February 2017. All procedures and handling of experimental animals were conducted in accordance with the Ethics Committee on Animal Use - CEUA/ UVA Protocol No. 006.09.015.UVA.504.02.

The zootechnical data used in the economic analysis came from a research in which 20 non-castrated male lambs of morada nova breed were used, with initial average body weight of $17.30+3.74 \mathrm{~kg}$ (Table 1). The animals were distributed in a completely randomized design, arranged in four treatments, being diet without biscuit bran (BB) and diets containing 15,30 or $45 \%$ of BB in place of corn in the diet. The experimental diets consisted of Tifton 85 hay (harvested after 35 days of regrowth), corn grain, soybean meal, BB and limestone. For the composition of the diets, we considered the nutritional requirements recommended by the National Research Council [NRC] (2007) for lambs in the finishing phase with weight gain of $200 \mathrm{~g} \mathrm{day}^{-1}$ and late maturity. All diets were isoprotein and isoenergetic with a roughage:concentrate ratio of 30:70 (Table 2). 
Table 1

Average values of zootechnical parameters of Morada Nova lambs fed diets containing biscuit bran in place of corn

\begin{tabular}{|c|c|c|c|c|c|}
\hline \multirow{2}{*}{ Item } & \multicolumn{4}{|c|}{ Biscuit bran (\% in place of corn) } & \multirow{2}{*}{ MSE $^{1}$} \\
\hline & 0 & 15 & 30 & 45 & \\
\hline Initial live weight (kg) & 17.00 & 19.10 & 17.00 & 17.20 & 0.99 \\
\hline Final live weight (kg) & 26.70 & 29.90 & 27.90 & 28.60 & 0.86 \\
\hline Average daily gain (g day ${ }^{-1}$ ) & 173.00 & 188.00 & 196.00 & 204.00 & 10.80 \\
\hline Intake dry matter (g day $\left.{ }^{-1}\right)$ & 744.00 & 875.00 & 822.00 & 820.00 & 29.10 \\
\hline Feed conversion (kg DM kg-1 gain) & 4.30 & 4.65 & 4.19 & 4.02 & 0.36 \\
\hline Hot carcass weight (kg) & 12.90 & 14.70 & 13.50 & 13.70 & 0.50 \\
\hline Cold carcass weight $(\mathrm{kg})$ & 12.70 & 14.60 & 13.40 & 13.40 & 0.86 \\
\hline Cold carcass yield (\%) & 48.50 & 49.50 & 47.80 & 48.50 & 0.49 \\
\hline
\end{tabular}

${ }^{1}$ MSE: Mean standard error.

The BB consisted of sweet biscuit coproducts obtained from a bakery products factory in the city of Sobral. The BB had the following composition: $9.07 \%$ crude protein, $11.61 \%$ ether extract, $2.64 \%$ crude fiber and $3,681.83 \mathrm{kcal} \mathrm{kg}^{-1}$ of metabolizable energy based on dry matter. The BB was ground uniformly at $2 \mathrm{~mm}$ in a grain shredder machine and properly stored in plastic drums with a capacity of $200 \mathrm{~L}$ for daily supply to animals.
The results of the zootechnical parameters obtained were extrapolated to a rear with 72 lambs confined over a period of 56 days to reach the slaughter weight on average of 28 $\mathrm{kg}$, totaling 6.5 lots and 468 animals produced per year. This extrapolation was performed so that the economic and financial analysis could be carried out on a scientific basis and in scale economics, according to Araújo et al. (2020b). 


\section{Table 2}

Ingredient proportions and chemical compositions of the experimental diets

\begin{tabular}{|c|c|c|c|c|}
\hline \multirow{2}{*}{ Item } & \multicolumn{4}{|c|}{ Biscuit bran (\% in place of corn) } \\
\hline & 0 & 15 & 30 & 45 \\
\hline \multicolumn{5}{|l|}{ Ingredient ( $\mathrm{g} \mathrm{kg}^{-1}$ dry matter) } \\
\hline Tifton 85 hay & 302.00 & 301.00 & 300.00 & 299.00 \\
\hline Ground corn & 418.00 & 354.00 & 294.00 & 227.00 \\
\hline Soybean meal & 275.00 & 274.00 & 276.00 & 272.00 \\
\hline Biscuit bran & ---- & 66.00 & 134.00 & 197.00 \\
\hline Limestone & 5.00 & 5.00 & 5.00 & 5.00 \\
\hline \multicolumn{5}{|l|}{ Chemical composition ( $\left.\mathrm{g} \mathrm{kg}^{-1} \mathrm{DM}\right)$} \\
\hline Dry matter ( $\mathrm{g} \mathrm{kg}^{-1}$ fresh matter) & 966.00 & 966.00 & 967.00 & 967.00 \\
\hline Organic matter & 942.00 & 942.00 & 943.00 & 943.00 \\
\hline Crude protein & 218.00 & 217.00 & 218.00 & 216.00 \\
\hline Ether extract & 39.00 & 38.00 & 38.00 & 38.00 \\
\hline NDFap & 327.00 & 321.00 & 311.00 & 310.00 \\
\hline Acid detergent fiber & 168.00 & 166.00 & 160.00 & 161.00 \\
\hline Hemicellulose & 254.00 & 238.00 & 222.00 & 207.00 \\
\hline Cellulose & 142.00 & 140.00 & 135.00 & 136.00 \\
\hline Lignin & 25.00 & 25.00 & 24.00 & 25.00 \\
\hline Total carbohydrates & 685.00 & 686.00 & 686.00 & 689.00 \\
\hline Non-fiber carbohydrates & 358.00 & 365.00 & 376.00 & 379.00 \\
\hline Total digestible nutrients ${ }^{2}$ & 810.00 & 814.00 & 808.00 & 807.00 \\
\hline
\end{tabular}

${ }^{1}$ NDFap $=$ Neutral detergent fiber corrected for ash and protein. ${ }^{2}$ Obtained by the equation proposed by Sniffen, O'Connor, Van Soest, Fox and Russell (1992).

The economic and financial evaluation of the data was performed descriptively, using Excel $^{\circledast}$ spreadsheets, which were formulated according to the analysis of the cost of production and economic viability indicators derived from it (Guiducci, Alves, Lima, \& Mota, 2012). The investments related to the implementation of the production system were: aprisco with a total area of $144 \mathrm{~m}^{2}$, with $50 \%$ of this area covered and the other $50 \%$ constituting solarium (Table 3). In addition, the acquisition of a balance was part of the investment.
The economic analysis was based on the calculation of cost of production, which is represented by the sum of all resources (inputs) and operations (services) used in the production process. The variable cost was composed by food, health, labor, equipment maintenance, depreciation, and other costs (power of the wielder, specifications on zootechnics and electrical energy) (Guiducci, Alves, Lima, \& Mota, 2012). These expenses were raised based on product price quotes in Sobral-CE in January 2020. The costs of feeding were composed of the prices and 
quantities supplied of the ingredients of the diets, based on dry matter. As a labor cost, it was considered the maintenance of an employee on a temporary basis to manage a confined lot of 72 cycle $^{-1}$ animals. The remuneration was based on the minimum wage in force in
January 2020 ( $R \$ 1,045.00)$, but paid only in half a day, considering that there is no need for employees constantly in the simulated properties, as well as costs with social or labor charges (Araújo et al., 2020b).

\section{Table 3}

Average values of zootechnical parameters of Morada Nova lambs fed diets containing biscuit bran in place of corn

\begin{tabular}{lcccc} 
Items & Quantity & Unity & Unity price (R\$) & Total price (R\$) \\
\hline Wooden & 240 & Linear meter & 7.00 & $1,680.00$ \\
Roof & 72 & Square meter & 120.00 & $8,640.00$ \\
Trough & 18 & Linear meter & 17.00 & 306.00 \\
Fountain & 8 & Bucket & 6.00 & 48.00 \\
Workmanship & 6 & Diary & 100.00 & 600.00 \\
Balance & 1 & Piece & 200.00 & 200.00 \\
Wire & 1.000 & Linear meter & 0.50 & 500.00 \\
Total price & & & & $11,974.00$
\end{tabular}

The purchase price of the lambs was $R \$$ 6.00 the $\mathrm{kg}$ of live weight and the selling price was $\mathrm{R} \$ 15.00$ per $\mathrm{kg}$ of meat, without taking into account the type of cut, values based on the average quotation of the northeast region. Thus, the total revenue was formed from the commercialization of meat production, as can be seen in Table 1.

The indicators of economic efficiency were: total revenue (TR), total cost (TC), net income ( $\mathrm{NI})$, point of leveling $(\mathrm{PL})$ and total factor productivity (TFP), calculated according to Guiducci et al. (2012). The financial indicators considered were: net present value (NPV), annualized net present value (NPVa), term of return on investment (Payback), internal rate of return (IRR), modified internal rate of return (IRRm), profitability index (PI) and rate of profitability (RP), calculated according to Guiducci et al. (2012). Thus, it was simulated cash flows for the period of ten years.

For the realization of sensitivity analysis, the items that compose the cash flows from each system were studied individually. In this work, to perform sensitivity analysis, it was adopted the discount rate of $6 \%$ per year, considering a variation of $30 \%$, both favorable and unfavorable to the results of each system, i.e., the price of each item that compose the cash flow. From there, it was possible to observe what item had a greater effect on the indicator of economic outcome. 


\section{Results and Discussion}

Food, the purchase of animals, and labor costs were the items that contributed most to production costs in the scenarios evaluated (Table 4). The highest food costs were observed when using the BB based diet at the replacement level of $15 \%$, which represents about $32.86 \%$ of the total costs. In monetary values, this lamb rearing spends more on food ( $R$ \$ 27,090.45/year), which corresponds to $\mathrm{R} \$ 57.88$ per lamb/year. The annual costs to produce lambs found in this study corroborate with the values found by several authors (Dal Monte et al., 2010; Barros et al., 2015; Paim et al., 2011; Pinto, Costa, \& Nobrega, 2014; Stivari et al., 2014) who observed that food spending is usually the item that most impacts the total cost of production of ruminants. The diet without $\mathrm{BB}$ was the one with the lowest food cost ( $R \$ 22,383.10)$ in monetary and percentage terms, accounting for about $28.79 \%$ of the total costs. Thus, the use of corn as an energy food, despite providing less performance to the animals (Table 1) provided lower food costs.

\section{Table 4}

Annual costs for the production of $\mathbf{4 6 8}$ Morada Nova lambs confined and fed diets containing biscuit bran in place of corn (value in real and percentage for each component)

\begin{tabular}{lcccc}
\hline Item & \multicolumn{4}{c}{ Biscuit bran (\% in place of corn) } \\
& 0 & 15 & 30 & 45 \\
\hline \multirow{2}{*}{ Alimentation } & $22,383.10$ & $27,090.45$ & $24,300.24$ & $24,032.36$ \\
& $(28.79 \%)$ & $(32.86 \%)$ & $(30.51 \%)$ & $(30.27 \%)$ \\
Sanity & 508.80 & 508.80 & 508.80 & 508.80 \\
& $(0.65 \%)$ & $(0.62 \%)$ & $(0.64 \%)$ & $(0.64 \%)$ \\
Workmanship & $12,540.00$ & $12,540.00$ & $12,540.00$ & $12,540.00$ \\
Other Costs 1 & $(16.13 \%)$ & $(15.21 \%)$ & $(15.74 \%)$ & $(15.80 \%)$ \\
& 106.00 & 106.00 & 106.00 & 106.00 \\
Acquisition of animals & $(0.14 \%)$ & $(0.13 \%)$ & $(0.13 \%)$ & $(0.13 \%)$ \\
& $39,780.00$ & $39,780.00$ & $39,780.00$ & $39,780.00$ \\
Support & $(51.17 \%)$ & $(48.25 \%)$ & $(49.94 \%)$ & $(50.11 \%)$ \\
\hline \multirow{2}{*}{ Depreciation } & 614.55 & 614.55 & 614.55 & 614.55 \\
& $(0.79 \%)$ & $(0.74 \%)$ & $(0.77 \%)$ & $(0.77 \%)$ \\
\hline
\end{tabular}

${ }^{1}$ Tax on Rural Land Ownership and Incra. 
In all types of animal production, food costs represent the largest share of total costs, as shown by Rogério et al. (2019). The farms using higher amounts of BB (30 and $45 \%)$ had lower food costs when compared to treatment using lower amounts (15\%). Therefore, the use of BB is a viable alternative, since its use in higher amounts in the diet provides reasonable performances for the animals and, consequently, greatly reduces the costs. According to the NRC (2007), the use of alternative foods is a viable option in animal production, as long as they are used in adequate quantities without harming animal performance, which was observed in the present study. Ideally, these foods should be used according to the availability in the region so that transportation costs are minimized. Moreover, it is crucial that the chemical composition of these foods is suitable for animal use (Rogério et al., 2013).

One of the great obstacles for producing lambs is the high mortality from diseases that affect the herd (Vieira et al., 2018). However, animal health costs were below $1 \%$ of the capital required to maintain the 468 Morada Nova lambs within a year, which shows that despite the great health difficulty faced by lamb producers, drug and treatment expenses represented just a small portion of annual costs. Similarly, the maintenance of facilities and improvements were the factors with the lowest cost in all simulations, ranging from 0.74 to $0.70 \%$. Although labor remuneration is the same for all treatments, the percentage allocated to this factor was higher when the diet without BB was used to produce Morada Nova lambs (16.13\%). In contrast, lamb production using the BB based diet at the replacement level of $15 \%$ required a lower labor force in percentage terms (15.21\%), but with the same monetary value as the others.

The cost of the diet without BB was $\mathrm{R} \$ 1.16$ per kilo (Table 5), that is, 1 cent more expensive than the diet with a lower amount of $\mathrm{BB}$, and 3 and 2 cents more expensive than diets with 30 and $45 \%$ of $\mathrm{BB}$, respectively. Within a year, feeding a batch with 468 lambs requires $19,255.39 \mathrm{~kg}$ of food without BB, 23,526.83; $21,382.92$, and $21,429.72 \mathrm{~kg}$ for production with $15 ; 30$ and $45 \% \mathrm{BB}$, respectively. In the diet containing $15 \% \mathrm{BB}$, the participation of roughage in the annual percentage costs was lower (29.72\%). However, the costs with roughage were higher in absolute terms $(R \$$ 8,050.81). 
Table 5

Average values of zootechnical parameters of Morada Nova lambs fed diets containing biscuit bran in place of corn

\begin{tabular}{|c|c|c|c|c|c|}
\hline Ingredients & $\begin{array}{c}\text { Annual } \\
\text { quantity (kg) }\end{array}$ & $\begin{array}{c}\text { Cost per } \\
\text { kilogram }(R \$)\end{array}$ & $\begin{array}{c}\text { Annual } \\
\text { Cost (R\$) }\end{array}$ & $\begin{array}{l}\text { Cost per } \\
\text { animal (R\$) }\end{array}$ & (\%) \\
\hline & \multicolumn{5}{|c|}{$0 \%$} \\
\hline Tifton 85 hay & $5,857.02$ & 1.14 & $6,677.00$ & 14.27 & 29.83 \\
\hline Ground corn & $8,082.36$ & 0.84 & $6,789.18$ & 14.51 & 30.33 \\
\hline Soybean meal & $5,218.20$ & 1.40 & $8,880.94$ & 18.96 & 39.63 \\
\hline Biscuit bran & - & - & - & - & - \\
\hline Limestone & 97.81 & 0.47 & 45.97 & 0.10 & 0.21 \\
\hline \multirow[t]{2}{*}{ Total } & $19,255.39$ & 1.16 & $22,393.09$ & 47.84 & 100.00 \\
\hline & \multicolumn{5}{|c|}{$15 \%$} \\
\hline Tifton 85 hay & $7,062.12$ & 1.14 & $8,050.81$ & 17.20 & 29.72 \\
\hline Ground corn & $8,353.80$ & 0.84 & $7,017.19$ & 14.99 & 25.90 \\
\hline Soybean meal & $6,519.24$ & 1.40 & $11,082.70$ & 23.68 & 40.91 \\
\hline Biscuit bran & $1,474.20$ & 0.60 & 884.52 & 1.89 & 3.27 \\
\hline Limestone & 117.47 & 0.47 & 55.20 & 0.12 & 0.20 \\
\hline \multirow[t]{2}{*}{ Total } & $23,526.83$ & 1.15 & $27,090.42$ & 57.88 & 100.00 \\
\hline & \multicolumn{5}{|c|}{$30 \%$} \\
\hline Tifton 85 hay & $6,416.28$ & 1.14 & $7,314.55$ & 15.63 & 30.10 \\
\hline Ground corn & $6,257.16$ & 0.84 & $5,256.01$ & 11.23 & 21.63 \\
\hline Soybean meal & $5,924.88$ & 1.40 & $10,072.29$ & 21.52 & 41.45 \\
\hline Biscuit bran & $2,681.64$ & 0.60 & $1,608.98$ & 3.44 & 6.62 \\
\hline Limestone & 102.96 & 0.47 & 48.39 & 0.10 & 0.20 \\
\hline \multirow[t]{2}{*}{ Total } & $21,382.92$ & 1.13 & $24,300.22$ & 51.92 & 100.00 \\
\hline & \multicolumn{5}{|c|}{$45 \%$} \\
\hline Tifton 85 hay & $6,430.32$ & 1.14 & $7,330.56$ & 15.66 & 30.50 \\
\hline Ground corn & $4,928.04$ & 0.84 & $4,139.55$ & 8.85 & 17.22 \\
\hline Soybean meal & $5,938.92$ & 1.40 & $10,096.16$ & 21.57 & 42.01 \\
\hline Biscuit bran & $4,029.48$ & 0.60 & $2,417.68$ & 5.17 & 10.06 \\
\hline Limestone & 102.96 & 0.47 & 48.39 & 0.10 & 0.20 \\
\hline Total & $21,429.72$ & 1.12 & $24,032.34$ & 51.35 & 100.00 \\
\hline
\end{tabular}

The simulation for the production of 468 Morada Nova lambs provided revenue higher than the production costs in all simulations, resulting in positive economic indicators (Table 6). We highlight the revenue generated when using $15 \%$ BB in the diet, which was $\mathrm{R} \$$
$103,194.00 /$ year, providing a net income of $\mathrm{R} \$$ $20,747.80$. This value corresponds to 19.85 minimum wages in force in 2020 , that is, the producer who chooses this type of creation gains $\mathrm{NI} 1.65$ minimum wages per month, which is a highly attractive value. All production 
scenarios showed a point leveling $(\mathrm{PL})$ greater than $5,000 \mathrm{~kg}$ of meat, and when using the diet without $\mathrm{BB}$, the amount to be produced within a year for the system to be economically feasible is the smallest, about 5,182 $\mathrm{kg}$. In contrast, when using the BB based diet with the inclusion of only $15 \% \mathrm{BB}$, this value increases by 313.82 $\mathrm{kg}$. When higher amounts of BB are added in the diet, the amount of meat to be produced so that the systems are economically viable decreases, by 186.01 and $203.87 \mathrm{~kg}$ less for the 30 and $45 \%$ concentrations, respectively, when compared to the diet with the inclusion of $15 \%$ BB.

\section{Table 6}

Average values of zootechnical parameters of Morada Nova lambs fed diets containing biscuit bran in place of corn

\begin{tabular}{lcccc} 
& \multicolumn{4}{c}{ Biscuit bran (\% in place of corn) } \\
\cline { 2 - 5 } Item & 0 & 15 & 30 & 45 \\
\hline TR1 (R\$) & $89,856.00$ & $103,194.00$ & $94,770.00$ & $96,174.00$ \\
TC2 (R\$) & $77,738.85$ & $82,446.20$ & $79,655.99$ & $79,388.11$ \\
NI3 (R\$) & $12,117.15$ & $20,747.80$ & $15,114.01$ & $16,785.89$ \\
PL4 (kg carcasses) & $5,182.59$ & $5,496.41$ & $5,310.40$ & $5,292.54$ \\
RRe5(\%) & 15.59 & 25.17 & 18.97 & 21.14 \\
TFP6 (R\$) & 1.16 & 1.25 & 1.19 & 1.21
\end{tabular}

${ }^{1} \mathrm{TR}$ : total revenue (sale of carcasses); ${ }^{2} \mathrm{TC}$ : total costs; ${ }^{3} \mathrm{Nl}$ : Net income; ${ }^{4} \mathrm{PL}$ : Point leveling (kg carcasses); ${ }^{5} \mathrm{RRe}$ : rate of return the entrepreneur; ${ }^{6} \mathrm{TFP}$ : total factor productivity.

Another interesting indicator was total factor productivity (TFP). All simulations showed TFP greater than 1, which indicates that for every $\mathrm{R} \$ 1.00$ invested in the activity, more than $\mathrm{R} \$ 1.00$ is generated to the producer in gross income, making them economically viable. In general, the producer using the diet without $\mathrm{BB}$ is the one that earns less, about 16 cents for every dollar invested. The producer using $15 \% \mathrm{BB}$, in turn, has the highest TPF, about 25 cents. Finally, 19 and 21 cents result from 30 and $45 \% \mathrm{BB}$, respectively.
The financial analysis showed that the diets were viable over 10 years (Table 7). Both net present value (NPV) and annualized net present value (NPVa) showed highly attractive values. A higher NPV is observed when using the diet with $15 \% \mathrm{BB}(\mathrm{R} \$ 362,143.26)$. Although the production of Morada Nova lambs without BB showed positive NPV, it showed a slightly lower value ( $\mathrm{R} \$ 298,620.92)$ compared to other types of production. All diets showed a low return on investment (payback), with values being close after two years. 


\section{Table 7}

Financial analysis of the production of Morada Nova lambs confined and fed diets containing biscuit bran in place of corn

\begin{tabular}{lcccc} 
& \multicolumn{4}{c}{ Biscuit bran (\% in place of corn) } \\
\cline { 2 - 5 } Item & 0 & 15 & 30 & 45 \\
\hline $\mathrm{NPV}^{1}$ (R\$) & $298,6203.92$ & $362,143.26$ & $320,678.01$ & $332,983.22$ \\
\hline $\mathrm{NPVa}^{2}(\mathrm{R} \$)$ & $40,573.02$ & $49,203.67$ & $43,569.87$ & $45,241.75$ \\
\hline Payback (years) & 1.91 & 1.76 & 1.85 & 1.82 \\
$\mathrm{IRR}^{3}$ (\%) & 116.72 & 138.70 & 124.36 & 128.61 \\
$\mathrm{IRRm}^{4}$ (\%) & 31.44 & 33.72 & 32.27 & 32.72 \\
$\mathrm{PI}^{5}$ & 8.60 & 10.21 & 9.16 & 9.47 \\
$\mathrm{RP}^{6}$ (\%) & 759.46 & 921.02 & 815.56 & 846.85
\end{tabular}

${ }^{1} \mathrm{NPV}$ : Net Present Value; ${ }^{2} \mathrm{NPVa}$ : Net Present Value Annual; ${ }^{3} \mathrm{RR}$ internal rate of return; ${ }^{4} \mathrm{RR}$ : modified internal rate of return (\%); ${ }^{5 P I}$ Profitability Index; ${ }^{6} \mathrm{RP}$ : Rate of profitability.

The sensitivity analysis (Table 8) showed that despite the changes in the price of commercialized meat or the quantity produced in several scenarios, the economic performance indicators showed that the production of lambs without BB in the diet was still economically viable, even in the least favorable situation, with a $30 \%$ reduction. In the most unfavorable scenario, for example, NPV was $\mathrm{R} \$ 135,539.64$ with a 2.13-year payback, a positive internal rate of return (IRR) of $23.06 \%$, well above the attractiveness rate of $6 \%$, which shows that the activity is economically viable even when the price of meat and the level of production are reduced by $30 \%$ as the profitability index was above 1, showing efficiency in this scenario. 
Table 8

Financial analysis of the production of Morada Nova lambs confined and fed diets containing biscuit bran in place of corn

\begin{tabular}{|c|c|c|c|c|c|c|c|}
\hline \multicolumn{2}{|c|}{ Combination } & \multicolumn{6}{|c|}{ Financial performance indicators } \\
\hline \multirow[t]{2}{*}{ Price } & \multirow[t]{2}{*}{ Quantity } & $\begin{array}{l}\text { NPV1 } \\
\text { (R\$) }\end{array}$ & $\begin{array}{c}\text { Payback } \\
\text { (years) }\end{array}$ & $\begin{array}{c}\text { IRR2 } \\
(\%)\end{array}$ & $\begin{array}{l}\text { IRRm3 } \\
\text { (\%) }\end{array}$ & $\begin{array}{l}\mathrm{Pl} 4 \\
(\%)\end{array}$ & $\begin{array}{l}\text { RP5 } \\
\text { (\%) }\end{array}$ \\
\hline & & \multicolumn{6}{|c|}{$0 \%$} \\
\hline $30 \%$ & $30 \%$ & $532,348.43$ & 0.56 & 188.61 & 38.53 & 14.54 & $1,353.89$ \\
\hline $20 \%$ & $20 \%$ & $466,213.63$ & 0.64 & 165.76 & 36.84 & 12.86 & $1,185.69$ \\
\hline $10 \%$ & $10 \%$ & $400,078.83$ & 0.74 & 142.91 & 34.94 & 11.17 & $1,017.49$ \\
\hline$-10 \%$ & $-10 \%$ & $267,809.24$ & 1.10 & 97.22 & 30.19 & 7.81 & 681.10 \\
\hline$-20 \%$ & $-20 \%$ & $201,674.44$ & 1.45 & 74.40 & 27.07 & 6.13 & 512.91 \\
\hline \multirow[t]{2}{*}{$-30 \%$} & $-30 \%$ & $135,539.64$ & 2.13 & 51.64 & 23.06 & 4.45 & 344.71 \\
\hline & & & & $15 \%$ & & & \\
\hline $30 \%$ & $30 \%$ & $625,321.42$ & 0.48 & 220.73 & 40.64 & 16.90 & $1,590.34$ \\
\hline $20 \%$ & $20 \%$ & $549,369.74$ & 0.55 & 194.49 & 38.94 & 14.97 & $1,397.18$ \\
\hline $10 \%$ & $10 \%$ & $473,418.05$ & 0.63 & 168.25 & 37.04 & 13.04 & $1,204.01$ \\
\hline$-10 \%$ & $-10 \%$ & $321,514.69$ & 0.92 & 115.76 & 32.30 & 9.18 & 817.69 \\
\hline$-20 \%$ & $-20 \%$ & $245,563.01$ & 1.20 & 89.54 & 29.21 & 7.25 & 624.52 \\
\hline \multirow[t]{2}{*}{$-30 \%$} & $-30 \%$ & $169,611.32$ & 1.72 & 63.35 & 25.27 & 5.31 & 431.36 \\
\hline & & & & $30 \%$ & & & \\
\hline $30 \%$ & $30 \%$ & $565,255.76$ & 0.53 & 199.98 & 39.31 & 15.38 & $1,437.58$ \\
\hline $20 \%$ & $20 \%$ & $495,504.22$ & 0.60 & 175.88 & 37.61 & 13.60 & $1,260.18$ \\
\hline $10 \%$ & $10 \%$ & $425,752.67$ & 0.70 & 151.78 & 35.71 & 11.83 & $1,082.79$ \\
\hline$-10 \%$ & $-10 \%$ & $286,249.58$ & 1.02 & 103.58 & 30.95 & 8.28 & 728.00 \\
\hline$-20 \%$ & $-20 \%$ & $216,498.04$ & 1.35 & 79.51 & 27.83 & 6.51 & 550.61 \\
\hline \multirow[t]{2}{*}{$-30 \%$} & $-30 \%$ & $146,746.49$ & 1.97 & 55.48 & 23.83 & 4.73 & 373.21 \\
\hline & & & & $45 \%$ & & & \\
\hline $30 \%$ & $30 \%$ & $580,661.04$ & 0.52 & 205.30 & 39.66 & 15.77 & $1,476.76$ \\
\hline $20 \%$ & $20 \%$ & $509,876.13$ & 0.59 & 180.84 & 37.98 & 13.97 & $1,296.73$ \\
\hline $10 \%$ & $10 \%$ & $439,091.23$ & 0.68 & 156.38 & 36.09 & 12.17 & $1,116.71$ \\
\hline$-10 \%$ & $-10 \%$ & $297,521.43$ & 0.99 & 107.48 & 31.40 & 8.57 & 756.67 \\
\hline$-20 \%$ & $-20 \%$ & $226,736.53$ & 1.29 & 83.04 & 28.33 & 6.77 & 576.64 \\
\hline$-30 \%$ & $-30 \%$ & $155,951.63$ & 1.86 & 58.65 & 24.43 & 4.97 & 396.64 \\
\hline
\end{tabular}

${ }^{1} \mathrm{NPV}$ : Net Present Value; ${ }^{2} \mathrm{RR}$ internal rate of return; ${ }^{3} \mathrm{RRm}$ : modified internal rate of return (\%); ${ }^{4} \mathrm{PI}$ : Profitability Index; ${ }^{5} \mathrm{RP}$ : Rate of profitability.

The diet containing 15\% BB showed an even greater variation than the diet without this alternative food. Considering a more pessimistic scenario, with a $30 \%$ reduction in production and product price, the internal rate of return was $63.35 \%$, showing that the best option in this scenario is to feed the Nova Morada lambs with a $15 \%$ BB based 
diet. Conversely, the scenario in which $30 \%$ $\mathrm{BB}$ is used and meat production and price are reduced by $30 \%$ shows a favorable outcome, since the use of BB in this condition was economically viable, with an NPV of R\$ $146,746.49$. These values indicate that the use of this diet allows the producer to remain in the activity for a long time, mainly due to the low payback time, with a return on investment of 1.97 years.

The production of Morada Nova lambs fed with higher amounts of BB showed less variation than the other levels of inclusion. In general, performance indicators were positive in the scenario with a greater negative variation in prices and quantity produced. Compared to the other indicators, IRR was above the attractiveness rate even in the most pessimistic scenario.

\section{Conclusion}

The highest productivity is achieved when choosing to rear lambs fed $45 \%$ of BB in the diet, while the highest recipes are obtained when using $15 \%$ of BB. The use of this alternative food makes food costs higher, but higher productivity provides higher revenue, making them more economically efficient, especially in certain situations where the price of meat is valued. The costs of feeding, acquiring animals and labor were the items that were most charged in all scenarios evaluated.

\section{References}

Araújo, R. A., Neiva, J. N. M., Pompeu, R. C. F. F., Cândido, M. J. D., Rogério, M. C. P., Lucas, R. C.,... Egito, A. S. (2018). Feeding behavior and physiological parameters of rearing goats fed diets containing detoxified castor cake. Semina Ciências Agrárias, 39(5), 2247-2260. doi: 10.5433/16790359.2018v39 n5p2247

Araújo, R. A., Pompeu, R. C. F. F., Cândido, M. J. D., Rogério, M. C. P., Lucas, R. C., Maranhão, S. R.,... Neiva, J. N. M. (2020a). Detoxified castor in the diets of dairy goats: I. Effects on intake, digestibility, and renal and hepatic parameters. Revista Brasileira de Zootecnia, 49(1), 1-9. doi: 10.37496/rbz 4920190141

Araújo, R. A., Pompeu, R. C. F. F., Silva, L. N. C., Rogério, M. C. P., Martins, E. C., Cândido, M. J. D.,... Neiva, J. N. M. (2020b). Economicfinancial analysis of the use of the detoxified castor by alkaline solutions I: production of arrays of dairy goats. Semina Ciências Agrárias, 41(6), 2247-2260. doi: 10. 5433/1679-0359.2020v41n6p2705

Arriba, R., \& Andrés, A. S. (2014). Production and productivity in Eastern and Western European sheep farming: a comparative analysis. Livestock Research for Rural Development, 21(1), 1-15.

Barros, M. C. C., Marques, J. A., Silva, R. R., Silva, F. F., Silva, F. F., Costa, L. T.,... Gusmão, J. J. N. (2015). Economic viability of crude glycerin in diets for lambs finished in feedlot. Semina: Ciências Agrárias, 36(1), 443-452. doi: 10.5433/1679-0359.2015v3 $6 \mathrm{n} 1 \mathrm{p} 443$

Bortoli, E. C., Monteiro, A. L. G., Gameiro, A. H., \& Bianchi, A. E. (2018). Determinação e composição de custos e receitas em sistemas de produção de ovinos para carne no estado do Paraná. Custos e Agronegocio On Line, 14(1), 144-181.

Dal Monte, H. L., Costa, R. G., Holanda, E. V., Jr., Pimenta, E. C., F., Cruz, G. R. R., \& Menezes, 
M. P. C. (2010). Calculation of the costs and evaluation of incomes in different systems of production of goat milk in Cariris Paraibanos. Revista Brasileira de Zootecnia, 39(11), 2535-2544. doi: 10.1590/S1516-35 982010001100029

Guiducci, R. C. N., Alves, E. R. A., Lima, J. R., $F^{\circ}$., \& Mota, M. M. (2012). Aspectos metodológicos da análise de viabilidade econômica de sistemas de produção. In R. C. N. Guiducci, J. R. Lima Fo., \& M. M. Mota (Ed.), Viabilidade econômica de sistemas de produção agropecuários: metodologia e estudos de caso (pp. 17- 78). Brasília, DF: EMBRAPA.

National Research Council (2007). Nutrient requirements of small ruminants: sheep, goats, cervids, and new world camelids. Washington D.C.: The National Academies Press.

Paim, T. P., Cardoso, M. T. M., Borges, B. O., Gomes, E. F., Louvandini, H., \& Mcmanus, C. (2011). Estudo econômico da produção de cordeiros cruzados confinados abatidos em diferentes pesos. Ciência Animal Brasileira, 12(1), 48-57. doi: 10.5216/cab. v12i1.5894

Pinto, C. W. C., Costa, J. M. O., \& Nobrega, J. E., Jr. (2014). Alternativa para produção de cordeiros Santa Inês em confinamento, alimentados com subprodutos da agroindústria. Revista Agropecuária Técnica, 35(2), 185-190. doi: 10.11606/ issn.1678-4486.v351i2p185-013

Rogério, M. C. P., Castro, E. M., Martins, E. C., Monteiro, J. P., Silva, K. M., Cândido, M. J. D.,... Costa, H. H. A. (2013). Economical and financial analysis of lamb finishing fed with diets formulated according to the NRC (1985) and the NRC (2007). Tropical
Animal Health and Production, 45(1), 259266. doi: 10.1007/s11250-012-0210-5

Rogério, M. C. P., Martins, E. C., Shiotsuki, L., Pompeu, R. C. F. F., Muir, J. P., Araújo, A. R.,... Alves, A. A. (2019). Economic viability of finishing lambs in the feedlot using bovine cheese whey as a dietary ingredient. Small Ruminant Research, 170(2), 131-136. doi: 10.1016/j.smallrumres.2018.11.018

Sniffen, C. J., O'Connor, J. D., Van Soest, P. J., Fox, D. G., \& Russel, J. B. (1992). A net carbohydrate and protein system for evaluating cattle diets: II. Carbohydrate and protein availability. Journal of Animal Science, 70(11), 3562-3577. doi: 10.2527/1992.70113562x

Stivari, T. S. S., Chen, R. F. F., Gameiro, A. H., Monteiro, A. L. G., Raineri, C., \& Silva, J. B. A. (2014). Feasibility of grazing sheep production systems using long-term economic indicators and the methodology of the soil expectation value. Brazilian Journal of Veterinary Research and Animal Science, 51(2), 149-157. doi: 10.11606/ issn.1678-4456.v51i2p149-157

Viana, J. G. A., Moraes, M. R. E., \& Dorneles, J. P. (2015). Dinâmica das importações de carne ovina no Brasil: análise dos componentestemporais. Semina:Ciências Agrárias, 36(3), 2223-2234. doi: 10.54 33/1679-0359.2015v36n3Supl1p2223

Vieira, V. D., Riet-Correa, W. R., Vilela, V. L. R., Medeiros, M. A., Batista, J. A., Melo, L. R. B.,... Riet-Correa, F. (2018). Controle de parasitas gastrintestinais em ovinos e análise financeira de uma fazenda com sistema de pastejo rotacionado irrigado no semiárido nordestino. Pesquisa Veterinária Brasileira, 38(5), 913-919. doi: 10.1590/1678-5150-PVB-5400 